\title{
Visible Identities: In Search of Egypt's Jews in Early Islamic Egypt
}

\author{
Petra Sijpesteijn
}

When the Arabs arrived in Egypt in the mid-seventh century (CE), they reportedly encountered substantial Jewish communities in Alexandria and at the Roman fortress of Babylon at the point where the Nile enters the Delta. Descriptions of synagogues, courts and religious educational institutions suggest a well-organised and functioning religious community. References to Jewish Egyptians in documentary sources, however - Greek, Coptic and Arabic papyri and inscriptions - remain scanty in the first two centuries of Muslim rule in Egypt. To quote Maged Mikhail's recent historical study of the period, 'Richly documented throughout Late Antiquity and especially from the late tenth century on, Egyptian Jews are marginally attested in the sources of the centuries under investigation [i.e., the early post-conquest centuries]. This prevents even a cursory survey' (Mikhail 2014, 9). Only from the ninth century do Jewish Egyptians become more visible in the documents. Three questions follow from this observation. (1) How to explain the absence of Jews in the documentary record from the first two centuries of Arab rule in Egypt? (2) What caused the increase in attestations from the ninth century onwards? (3) Does this signify an increase in the Jewish Egyptian population or are other factors at play? In this paper I will argue that the introduction of ethnic-religious identity markers in the written record in the ninth century is best explained by demographic changes and the consequent socio-political re-orientations related to these changes.

1 Another version of this article has been arranged to appear under the same title in Elisabeth R. O'Connell (ed.), Egypt, empire and the formation of religious identity (c. $30 B C-A D$ 19oo), British Museum Publications on Egypt and Sudan 11 (Leuven: Peeters, forthcoming). It is based on a presentation I held at the 2015-conference 'Egypt and empire: Religious identities from Roman to modern times' at the British Museum. I would like to thank Eve Krakowski, Susanna de Vries, Nicholas de Lange, Adam Silverstein, Luk van Rompay, and Jelle Bruning for their help in providing references and feedback. Any remaining mistakes are entirely my own. This work was supported by the European Research Council under Grant number 683194. 
Arabic literary sources reporting on Egypt under the first centuries of Muslim rule abound. Chronicles, geographical dictionaries and local histories provide information on historical events and on the human and natural environment, starting with the conquest and even pre-dating it. The earliest and doubtlessly richest source is Ibn 'Abd al-Ḥakam's (d. 870) Conquest of Egypt (Futūḥ Mișr). As Hugh Kennedy has pointed out this text is written to record the achievements of the Arabs who had conquered and subsequently ruled Egypt, but who had lost their privileged position to Persio-Turkish Muslims who had immigrated to Egypt from the eastern part of the empire from the 83os onwards (1998). In this sense it is a valuable source not only for the earliest period under examination, but especially for the demographic and consequent social changes taking place in the ninth century. From the tenth century comes another rich source, al-Kindì's (d. 961), Book of governors and judges (Kitāb al-wulāt wa-kitāb al-qudāt), which was also produced in Egypt. Later Egyptian sources, such as al-Maqrizī's (d. 1442) description of the topography and history of Egypt (al-Mawāizz wa-l-itibār fì dhikr al-khițațwa-l-äthār) and Ibn Duqmāq's (d. 1407) description of Cairo (Kitāb al-intișār li-wāsițat 'iqd al-amșār), also preserve useful earlier material despite their late date of composition. Geographical and historical texts written outside the province contain useful information as well.

Documentary sources such as papyri and inscriptions from early Islamic Egypt are especially bountiful and useful sources to examine issues of selfidentification amongst Egypt's population. There are, however, some limitations to this material. Most of the papyri from the Islamic period are found in a limited number of rural findspots outside the main places of residence. A substantial number of Arabic papyri and ostraca dating to the ninth century were discovered in Fustat (Denoix 1986; Gayraud, Björnesjö and Denoix 1986, 25). Most papyri can only be roughly dated on the basis of the palaeography. Moreover, because most papyri have been found in disposal heaps, they lack an archaeological context. The individuals mentioned in the documents can mostly not be identified. Due to the haphazard composition of the papyrological remains, moreover, documents appear mostly in isolation without other texts related to the same events or individuals - thus offering only one side of a story.

Documents related to Egypt's Jewish community were partially produced by (and for) themselves, but documents produced by non-Jews also purposely or unintentionally record information. The most obvious are ethnic-religious

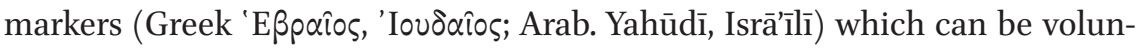
tarily used or imposed by others to describe individuals or groups. References 
to religious or community buildings and rituals, celebrations or any object or transaction related to the organisation thereof are attested as well. Religious and other literary and semi-literary texts such as amulets might be considered at first sight to be community specific but can, of course, have been consumed by other groups as well. Names are notoriously difficult identifiers (on all these issues, cf. Ilan 2016). ${ }^{2}$

As for the languages in use in Islamic Egypt, some changes occurred under the Arabs, while continuity prevailed in other ways. When the Arabs arrived in Egypt in 639, Arabic was immediately added to the languages already in use, namely Greek and Coptic. ${ }^{3}$ Greek remained the language most commonly used in the administration into the ninth century. The use of Coptic increased under the Arabs as it was also used to write administrative documents for the first time. Coptic and Syriac had already become more important in the Near East, possibly as a form of anti-Chalcedonian resistance, but no Christian Syriac or Palestinian Aramaic papyri are attested from Byzantine Egypt. ${ }^{4}$ The use of Hebrew (and Aramaic) in Egypt increased from the fifth century onwards, but the impact of the supposed introduction of Hebrew as a liturgical language in the sixth century left few traces in the documentary record (Stroumsa 2012; Smelik 2012; Sirat 1985; Ilan 2016). Both Syriac and Judeao-Arabic papyri are attested from the ninth century onwards (see below).

\section{The Jewish Population of Egypt at the Time of the Arab Conquest}

Let us begin with an overview of what the historical, literary and documentary sources say about Egypt's Jewish population on the eve of the Arab conquest. Documentary and literary sources suggest that Byzantine Egypt was home to a significant, religiously active and transregionally connected Jewish community residing both in towns and in the countryside (Ilan 2016). In spite of the reports of repeated expulsions of and attacks on the Jewish population of Alexandria by the Romans, a continuing Jewish presence in the city up to the Arab conquest is confirmed (Stroumsa 2012; Starr 1935, 281, 286). Presumably such expulsions were actually not applied to the whole Jewish population of

2 With Marie Legendre I am preparing a paper on onomastics as a tool to study Egypt's Jewish community.

3 From Late Roman Egypt date also a small number of Hebrew and Aramaic papyri (Sirat 1985; Ilan 2016) as well as a cache of very important but particular Syriac Manichaean texts found in the Dakhla oasis (Gardner 1996, 161-76).

4 For the small group of Syriac Manichaean papyri found in Dakhla, see above n. 3. For the increased use of Syriac in the seventh and eighth centuries, see Tannous 2018, 181-89. For the rise of Coptic in the sixth century, see Papaconstantinou 2008. 
the city, but rather imposed symbolically only on the Jewish leadership. There are suggestions that the Jewish population, in fact, increased in the early seventh century when refugees from Palestine fleeing the Persian armies settled in Alexandria (St John the Almsgiver 1980-1981; Ibn al-Bițīq 1985). Other sources point to a continued Jewish presence in the Egyptian countryside. The Babylonian Talmud contains a discussion on the permissibility of reading the book of Esther in Coptic (b. Meg. 18a). Probably related to the sixth-century debate within the Jewish community over whether scriptures should be read in public in Hebrew only, the reference points to the presence of a Jewish community in the Egyptian countryside which was in touch with the Babylonian religious authorities (Smelik 2012).

This Jewish community left its traces in Greek papyri where members are

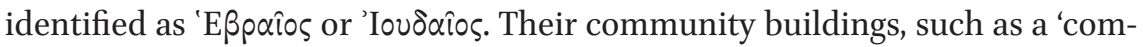
munal synagogue' in an account of one of the Appion estates in the Fayyüm dated to post-566 CE (P.Oxy. 55.3805), are mentioned as well. Hebrew and Aramaic papyri record Jewish marriage contracts, biblical, liturgical and magical texts (Sirat 1985; Ilan 2016). All in all, the documentary and literary evidence points to an intensified Jewish presence in Egypt from the fifth century onwards (Ilan 2016, 216-17).

The presence of a significant Jewish population in Egypt is confirmed by descriptions of the Arab conquest. These accounts concentrate on the cities, where the Arabs encountered a substantial and active Jewish population. It is reported that when the Arabs entered Alexandria in 642, there were 40 or 70 thousand Jews living there (Ibn 'Abd al-Ḥakam 1922, 81; Ibn Duqmāq 1893; Ibn al-Bițrīq 1985, §285, p. 147). Egypt's conqueror and first governor, 'Amr b. al-Āṣ (d. 664), subsequently determined in the treaty concluded in 641 with the city's patriarch that the Jews could remain in the city (John of Nikiu 1916, 194).

In and around the Roman fortress of Babylon several synagogues were located when the Arabs founded Fustat on the same spot at the entry of the Nile Delta (Dridi 2015; Stiefel 2014, 27). Amongst the eleven functioning synagogues in the Egyptian capital that al-Maqrīzì (d. 1442) mentions, he identifies four explicitly as dating back to the first or second century CE (al-Maqrīī 2002-2003, 4: 939). While such a date for continuously functioning synagogues might seem unlikely, it does suggest that these religious buildings were considered to be very old by the time al-Maqrīzī described them.

In fact, religious buildings, mosques, as well as churches and synagogues had to be built and expanded to serve the growing population of Fustat. Immigrants flowed into the capital from Egypt and beyond (Dridi 2015). That this growing population residing in the capital contained Jews is clear from other sources as well. The chief judge of Fustat, Khayr b. Nu'aym (in office 737-744) announced 
in $738-739$ that from then on evidence of Jews and Christians in cases against their co-religionists was acceptable in court (al-Kindī 1912, 351).

While there is thus strong indication that there was a significant Jewish population in Egypt during the first two centuries of Muslim rule, their presence in the documentary sources is very slim indeed. Greek papyri attest individuals

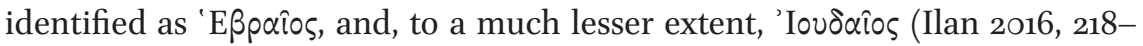
219), all but one produced by the Arab-Muslim administration. Greek writing on an ostracon records the contributions for the military provisions ( $\alpha \nu v \omega v \alpha)$

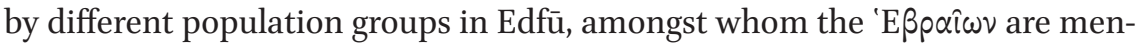
tioned. This text is dated to the very end of the Byzantine or early Arab period (Gascou 1978). A poll-tax receipt for Jakob 'Eßpoîos from the Fayyūm is dated 645 (SPP 8.741). Two fiscal lists dating to the eighth century from the Fayyūm include men identified as 'Eßpoîos (Levi and Abraham in P.Sijp. 36; Moses, Jacob and Orbi in SPP 10.182). The only non-administrative text is a seventhcentury receipt for rent made out to the lady ' $\Sigma \varepsilon v u$ $\varphi \varepsilon ı ~ ' E \beta \rho \varepsilon ̂$ ' (P.Brook 15). Only one Arabic document from the second half of the eighth century uses the qualifier 'the Jew' or 'Jewish.' Three generations of Jewish men, Jacob (Ya'qūb), his son Joseph (Yūsuf) and his grandson, were all identified 'al-Yahūdī' in an Arabic sale-contract dated $761-762$ for a mule (Hanafi 2004). While not many in number, the documents show a rather wide geographical spread throughout Egypt's countryside.

Interestingly, this period also yields only one Arabic document that uses the descriptive 'the Christian' or 'Christian.' In an eighth-century list of goods shipped for different individuals a Yasū' al-Nașrānī and a Mūsā al-Nașrānī appear (Khan 1992, no. 7). The adjective 'Christian' appears occasionally in seventh- and eighth-century Greek and Coptic legal documents to refer to Christian institutions such as monasteries and a Christian legal system or rulings (cf. Papaconstantinou 20og). In a Greek letter dating to the second half of the seventh century, 'Christian slaves' are requested to be sent from Edfū to the Arab authorities in Fustat (P.Apoll. 51). The description of the governor's retinue as 'Arab and Christian officials' in an early eighth-century Greek papyrus is probably a reference to the linguistic-administrative domains that these two groups of administrators occupied. The officials are the recipients of the food such as dates, sheep, vinegar, oil, boiled wine and poultry and firewood for which the maintenance costs (Ar. rizq; Gr. $\delta \alpha \pi \alpha \dot{v \eta}$ ) are demanded from the community of Aphroditō/Ishqūh (P.Lond. 4.1375). Famously, the Muslim-Arab conquerors are not religiously identified, but rather referred to in Greek as $\mu \omega \alpha \gamma \alpha p i \tau \alpha \iota$, probably a rendering of the Arabic word 'muhājirūn,' migrants. Greek and Coptic papyri attest the term moumin, a rendering of Arabic 'mu'minūn,' 'believers,' but only in the combination amirmoumin, which refers 
to the Arab administration as a whole and should not be understood as 'prince

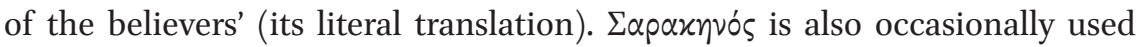

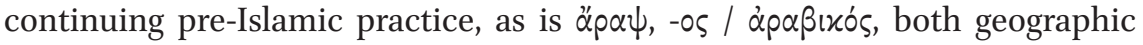
markers. ${ }^{5}$

Two further documents, one in Coptic and the other in Arabic, contain names that unambiguously refer to Jews, but without identifying them explicitly as Jewish. A seventh/eighth-century Coptic document concerning the leasing of land from Bawit mentions Eliezer son of Toual (?) as the lessee (Delattre, Pilette and Vantieghem 2015, no. 3). Finally, in a letter dating to the last quarter of the eighth century an individual named Judah (Yahūdā) appears (Jahn 1937, no. 10 republished as Diem 2018, no. 2). Many more Jewish Egyptians are presumably hidden in the documents behind less unambiguous names and markers. The small number of explicit attestations does not prove that there were hardly any Jews in Egypt at this time, but rather that identifying them in the written record as such, both as a group and as individuals, was not deemed necessary during the first two centuries of Muslim rule. To understand when and why this changed in subsequent centuries, we should examine the relation between the Arab ruling authorities and their Egyptian subjects.

\section{From People of the Land to Copts}

In the period immediately following the Arab conquest the distinction that mattered was that between conquerors and conquered, Arabs and Egyptians, soldiers and peasants. The Egyptians who had remained in possession of their properties after the Arab takeover, worked the land to raise the taxes that paid the Arab soldiers' stipends and provisions. Arabs and Egyptians occupied two distinctive hierarchical categories, and they also remained separated spatially, with the Arabs confined to the garrisons of Fustat and Alexandria. The distinction is reflected in the terms used to describe the two groups: soldiers (jund) for the Arabs versus 'people of the land' (ahl al-ard) for the Egyptians. The governor Qurra b. Sharīk (in office 709-715) uses these terms in his letters to the pagarch Basileios of the district of Aphroditō/Ishqūh in Upper Egypt in the years 709-710 (e.g., Grohmann 1938a, nos. 148, 159; Becker 1906, nos. 1-3; Abbott 1938, no. 2). Another term used to describe the Arab rulers is 'people of Egypt' (ahl Mișr) (Diem 1984, no. 1; Rāgiib 1981, no. 1). The name Mișr, introduced by the Arabs, was the current identification for the province in Arabia.

5 See for example the expression kata sarakēnous or kat'arabas to indicate the hijra calendar in Greek and Coptic papyri (Bagnall and Worp 2004, 300). 
This expression is also used to qualify the chief judge of Fustat ( $q \bar{a} d \bar{l}$ ahl Mișr ) in a papyrus letter from the Egyptian governor to the Nubian king dated $75^{8}$. This same text refers to the Christian Nubians as a religious community (ahl millatika) (Hinds and Sakkout 1981, 220, 222).

A new phase in Arab-Egyptian relations, which had an impact on the use of descriptive terms attested in the papyri starts in the mid-eighth century. This is when Arab-Muslim expansion extended into Egypt's countryside with Arab-Muslims taking possession of agricultural lands and settling outside the garrisons (Sijpesteijn 2013, 163-72). Arabicisation and Islamicisation, albeit still limited at this time, increased as a result. This in turn impacted the relation between rulers and ruled and how the two groups were identified in the written record. The changed vocabulary first occurs in documents related to taxation. A document dated ca. 735 enjoins Muslims (ahl al-Islām) in the Fayyūm to pay the alms-tax (șadaqa, zakāt) (Sijpesteijn 2013, no. 8), while both the terms ahl al-islām and muslimūn appear in a letter from the governor of Egypt to the king of Nubia dating to 758 (Hinds and Sakkout 1981, 220, 222).

Later in the eighth century, documents attest the use of the two categories 'Muslims' and 'people of the covenant of protection,' i.e., non-Muslims (ahl al-dhimma) as administrative entities (one such text is edited by Grohmann 1952a, 132-33; another text is dated to 790 by Diem 1984, no. 7). Copts (qibt) are opposed to Muslims in another eighth-century papyrus related to agricultural taxes (Sijpesteijn 2006, no. 1). Fiscal categories are also specified as 'Coptic' (baqțal-qibt; fudūl al-qibț) when referring to dues imposed on the indigenous population (Grohmann 1938b, nos. 2 and 4). Starting in the late ninth century Arabic fiscal and legal documents make frequent use of the expression 'months of the Copts' (shuhür al-qibt) in the date or 'calculation of the Copts' ('adad al-qibt) for the kind of payment requested. These terms are, however, used to indicate population groups as a whole, not individuals and seem to be used to identify non-Muslim Egyptian tax-paying peasants as opposed to Muslim ones, or even indigenous Egyptian practice as opposed to newly introduced (Arab) customs, without distinguishing between Christian and Jewish Egyptians. In fact, the term qibt does not seem to have a religious connotation at all. Copt, the Arab vulgarisation of the Greek Ailyv $\pi \tau$ ○ is after all a generic term applicable to all indigenous inhabitants of the province.

Processes of Islamicisation, Arabicisation and migration in the ninth century altered Egypt's population composition in both ethnic and religious terms. 
While the rate of conversion seems to have continued to be negligible, the impact of the movement of populations across the Empire and within Egypt did lead to the rise of communal-religious designations. The late eighth and early ninth century witnessed great changes in settlement patterns within Egypt and migration into the province from the eastern part of the Empire. The breakdown of central control gave new population groups a chance to expand their presence in the province, dramatically changing its social-ethnic organisation. Greater interaction led, on the one hand, to a levelling of differences, on the other, and partially in reaction to it, to greater distinction and sharper demarcation between groups. This directly impacted both how members of those communities self-identified and were classified. The documentary and literary record show how the application of identity markers used by and for individuals changed as a result.

From the late eighth century onwards, troops originating in the eastern Islamic empire (Persian-Turkish soldiers) had found their way to Egypt, introduced initially by governors and military leaders sent to govern the province. Political events at the end of the eighth and early ninth century reinforced this development. Representatives of the ruling military élite from the caliphal capital in Iraq, who had been settling in Egypt since the late eighth century, now began to take over land holdings and offices at the expense of Egypt's wujūh, the Arab families who had conquered and first settled Egypt in the seventh century. From the last decade of the eighth century the country came effectively under the control of a Persian-Turkish military élite initially based in Iraq. A semblance of order was restored by the Abbasid general 'Abd Allāh b. Taahir, but the measures he took during his short presence in the province (825 or 826-827) decisively further reduced the power of the old Arab leaders. Eastern appointees replaced local Arabs in such crucial positions as the police and head of the fiscal office (al-Kindī 1912, 183-84). With the administrators arrived personnel who introduced new administrative terminology and practices (Sijpesteijn 2011). In other words, support and co-operation from the local wujūh was no longer necessary, while a new class of administrators and bureaucrats was put in control of the province (Kennedy 1998).

The wujūh turned to other ways to make their presence felt in the province. It is exactly when their role in the administration diminishes that Arab-Muslim Egyptians appear more prominently in mediation processes of informal conflict resolution as can be observed in the papyri. In this arena, which fell outside the official legal and administrative institutional structures, the Arabs still wielded substantial power based on their standing amongst the local population (Sijpesteijn 2020). In other areas too, the wujüh's attempts at self-legitimisation can be observed. The first local history of Egypt, the Futūh 
Mișr is a conscious attempt to create the history and emphasise the importance of the Arabs who had settled in and ruled Egypt from the seventh century (Kennedy 1998). The writing of a history for the wujūh connecting them to the Egyptian land coincided with the development of an Egyptian Muslim identity under influence of the processes of Islamicisation and Arabicisation, which found expression in other literary genres (Sijpesteijn 2011).

Arab-Muslim settlement in the Egyptian countryside starting in the mideighth century had indeed led to increased Arabicisation and, to a lesser extent, Islamicisation (Sijpesteijn 2013, 163-72). The use of Arabic had been gradually increasing to the point that no securely dated Greek papyri can be identified after the first half of the ninth century. The use of Coptic diminished as well. The number of Arabic papyri, on the other hand, dramatically increases in the ninth century suggesting either that more Arabic speakers were settled in the Egyptian countryside or more Egyptians in the countryside used Arabic for their written communications (Sijpesteijn 2013, 235-36). While Egypt's Muslim population would continue to form a numerical minority for several centuries, intensified contact resulted in Islamicisation in cultural and religious terms as well (Brett 2005; Mikhail 2014).

Increased interaction between Arabs and Egyptians lay at the base of these developments and was stimulated by it. The result was cultural and social convergence. The opposing categories of Arab-Muslim ruling authorities and local Egyptians could even give way to a shared socio-economic and political agenda. In the eighth century Egyptians and Arabs together rose up against an increasingly intrusive central state (Lev 2012). Commercial transactions in which Muslims, Christians and Jews work together are recorded in Arabic, Coptic and Judaeo-Arabic letters.

The loss of distinctive communal identities also led to disaffection and protest. When the ninth/tenth-century author of the Apocalypse of Samuel of Qalamun warned against the use of the Arabic language and other forms of Arabicisation amongst the Egyptian Christians, he was fighting a losing battle. ${ }^{6}$ He was, however, expressing the discomfort of Egyptian Christians about the increasingly close interaction between the Christians and Muslims of Egypt (Papaconstantinou 2007). The author called for a strict adherence to Coptic cultural expressions and for a redefining of group identity on the basis of religious-ethnic terms. Indeed, the first occurrence of the 'era of the martyrs' in Egypt is found in a Coptic dating formula written in 861/2. This name ('era of the martyrs') probably arrived in Egypt from Nubia where it appears some 75 years earlier and became the dating method of choice in Egyptian Christian

6 For the arguments that this text is a product of ninth/tenth-century developments, see Hoyland 1997, 278ff 
texts (Bagnall and Worp 2004, 67). It is also in the ninth century that the restrictive measures concerning clothing, hair styles and other external markers designed to distinguish Muslims from non-Muslims were most probably systematised as the shurūt 'Umar (Cohen 1999; Yarbrough 2016. Pace Levy-Rubin 2016). In other words, at a time characterised by social unrest and political turmoil the call for clear demarcations and boundaries ostensibly to preserve existing identities, created a new norm of religious identification expressed in the literary and documentary record.

The results of these changes are obvious in the documentary record. Individuals appear in the papyri more frequently with a distinctively ethnic or religious nisba or name. In some cases, inter-confessional distinctions might have been expressed as well. This can be seen, for example, in the different terms - al-Yahūdī (Khan 1992, no. 33; Vanthiegem 2014, no. 2; David-Weill 1951-1952) and al-Isra'î̀i (Grohmann, 1952b, no. 248) — used to identify Jewish Egyptians. ${ }^{7}$ These documents all originate in an administrative-fiscal context. A ninth-century quittance records the payment of ten dinars by Sha'un al-Yahū dī to a certain Yazīd b. Yazīd (the unpublished Mich.Pap.B 111 from the Cambridge University Library). ${ }^{8}$ In a ninth-century letter an individual is identified as 'the son of the Christian woman' (Ibn al-Masinhiyya) (Diem 1997, no. 61).

While the previous texts can be considered to be the result of centralised directives, other papyri were produced by members of the community itself. The name Isrāîl (e.g., Grohmann 1952b, no. 248; Grohmann 1943, no. 71) occurs for the first time in ninth-century Arabic papyri. An unedited ninth-century letter mentions a certain Rabbi Judah (Yahūdā), the likes of whom the sender of the letter asks God to increase amongst the 'people of Israel' (banū Isrä'il)..$^{9}$ The name Judah (Yahūdā) also appears twice in a list of quittances by individuals whose names suggest they were all Jewish (the unpublished AP 11325 from the Austrian National Library). ${ }^{10}$ In addition, a small number of Judaeo-Arabic papyri are preserved (Blau and Hopkins 1987; Sirat 1985; Vantieghem 2014, no. 2). The documents do not bear dates, but on the basis of palaeography and the expressions used in them, they can be dated to the ninth century. Their origin, as far as it is known, is representative of the papyrological record in general, showing that Jewish communities were present throughout Egypt. Written in Arabic but in Hebrew characters, these documents clearly originate in a Jewish milieu. Judaeo-Arabic documents can be considered to continue the Hebrew Christians (Diem 1997, no. 41).

8 I would like to thank Jelle Bruning for bringing this text to my attention.

9 I am preparing the text for publication.

10 I would like to thank Jelle Bruning for bringing this text to my attention.
} 
and Aramaic writings of earlier centuries (Sirat 1985, Ilan 2016), but the large number of Judaeo-Arabic commercial letters shows a shift from a prevalently legal and religious use to the private-commercial sphere. Besides the Hebrew script the documents do not generally contain specific references to a 'Jewish context,' using the same religious blessings and formulae as contemporary nonJewish letters do. One letter, however, opens with the expression, 'in Thy Name, O Merciful One,' instead of the usual 'In the name of God, the Compassionate, the Merciful' (Blau and Hopkins 1987, 111). The Judaeo-Arabic letters do represent, however, features of early phonetic Judaeo-Arabic spelling which can, in a rudimentary form, also be observed in a group of three eighth-century Arabic papyri produced in a Jewish context (Diem 2018, 13-15 and the unpublished Arabic papyrus mentioned above n. 9).

The use of a distinctive language associated with a particular religious group can also be observed in the ninth-century Syrian orthodox community in Egypt. The ninth century witnessed important migration of Syrian orthodox Christians from Iraq and Syria to Egypt (Fiey 1963; Shaked 2010; Hunt 2003). Forming a successful mercantile community in the capital Fustat, they also fostered Syriac as a written language, albeit seemingly only in the literary domain. The library of the Dayr al-Sūryān monastery in the Wadī al-Natrūn was founded with Syriac manuscripts brought from Iraq and Syria. While there had always been Syrian orthodox Christians temporarily and permanently settled in Egypt, only from the ninth century onwards were new Syriac texts composed in monasteries throughout Egypt (Van Rompay 2008). The trend to make religious affiliations explicit through identity markers in writing continued in the tenth century. The appearance of the name 'Abd al-Masị in large numbers in the Arabic papyri shows the high level of acculturation amongst Egyptian Christians, who take over Arab-Muslim naming patterns ('Abd Allāh, etc.), but adding a Christian twist (Grohmann 1938a no. 195; Diem 2008 nos. 18 and 21). Jewish-named authors are known from this period for the first time since Hellenistic times (Rustow 2008, 36), namely the famous theologian and Judaeo-Arabic translator Sa'adya b. Joseph Gaon (d. 942) and the physician and philosopher Isaac Israeli (d. 955)). Although the two of them flourished outside Egypt (in Baghdad and Qayrawan respectively), both received their basic Jewish theological education in the province (Fenton 1995). Clearly, a Jewish intellectual and religious infrastructure had been in place in Egypt to train scholars before, but only now do we see Gaon and Israeli being brought to the forefront as representatives of the Jewish community. The desire to draw boundaries between religious communities also gave rise to the polemic and apologetic texts that flourished in the tenth century. 
When the Persian geographer Ibn Khurdādhbih (d. 912) described the position of the Jews of Alexandria he writes that the community had suffered an inferior status in the pre-Islamic period. Indeed, Egyptian Jews had suffered regular persecutions and expulsions under the Romans with some of the worst maltreatment after the Byzantine restoration of power in 628 as a punishment for Jewish collaboration with the Persians (Stillman 1997, 199). Orders to leave, however, were probably only seriously imposed on the Jewish leadership: a Jewish population had thus been able to continue to educate and practise their religion in Egypt up until the Islamic period. While the numbers of Egyptian Jews encountered by the Arabs according to the chronicles might have to be taken with a grain of salt, references to synagogues and educational institutions indicate that the community was active and considerably numerous. Documentary references in Hebrew, Greek and Arabic also show that a Jewish population existed throughout Egypt.

Egypt's demographic composition changed drastically in the ninth and tenth centuries under influence of Islamicisation, Arabicisation, as well as changed settlement patterns and immigration from the eastern Islamic empire. This brought about deep changes in Egypt's social organisation resulting in greater distinction and demarcation between ethnic and religious groups. In the changed social landscape, it became common to express group and individual identities religiously, ethnically and linguistically. An increased awareness and necessity to document religious and ethnic demarcations affected all sectarian groups in Egypt - Muslims, Christians and Jews - and manifested itself in new identity markers following similar patterns used in contemporary documents. Scripts (Hebrew) and languages (Syriac, Arabic) were applied in new contexts and on a larger scale by Egyptian communities to demarcate these communal boundaries. Nisbas and names referring to the ethnic and religious identity of individuals were used more frequently or appeared for the first time.

Egypt's Jews participated in these processes. Judaeo-Arabic commercial letters and other documents appear for the first time in the ninth century. Nisbas and other identity markers appear more frequently from the ninth/ tenth century onwards in the documents. The increased visibility of Egypt's Jews in the documentary record thus reflects a changed attitude towards the use of religious-ethnic markers in written texts in ninth-tenth century Egypt. While no substantial numerical change seems to have occurred in Egypt's Jewish population before the substantial influx of Jews (and Christians) under 
the Fatimids, migrations from Iraq in this period may have had some impact (Ashtor 1972; Rustow 2008). As discussed above, Syrian orthodox populations from Takrit in Iraq moved to Egypt, while soldiers and administrative personnel also moved from Baghdad and Khurasan to Egypt. In 882 a group of recently arrived Iraqi immigrés acquired a building from the Coptic patriarch for use as a synagogue (Stiefel 2014, 27). Amongst the earliest documents preserved in the Genizah of the Ben Ezra synagogue in Fustat are indeed some marriage and divorce contracts drawn up in Iraq and northern Syria, presumably brought to Egypt by Jewish immigrants (Olszowy-Schlanger 2006).

Egypt's Jewish population utilised Hebrew and Aramaic to compile biblical and liturgical texts and to educate youth in religious matters in the late Roman and early Islamic period. While occasionally using or being identified with religious-ethnic markers, the documentary record in these periods does not identify Egypt's Jews clearly. The ninth/tenth-century expressions of their religious identity, on the other hand, are more numerous and operate in new domains. When Ibn Khurdādhbih described the position of Egypt's Jews in his lifetime positively (compared to earlier times), he might have been influenced similarly by the augmented visibility and consequent increased presence of Jewish Egyptians.

\section{Bibliography}

Abbott, Nabia. 1938. The Kurrah Papyrifrom Aphrodito in the Oriental Institute. SAOC 15. Chicago, IL: The University of Chicago Press.

Ashtor, Eliyahu. 1972. "Un mouvement migratoire au haut Moyen Age: Migration de l'Irak vers les pays méditerranées." Annales 27: 185-214.

Bagnall, Roger S. and Klaas A. Worp. 2004. Chronological Systems of Byzantine Egypt. 2nd ed. Leiden: Brill.

Becker, Carl H. 19o6. Papyri Schott-Reinhardt I. Veröffentlichungen aus der Heidelberger Papyrus-Sammlung 3. Heidelberg: Winter.

Blau, Joshua and Simon Hopkins. 1987. "Judaeo-Arabic papyri: Collected, edited, translated and analysed." Jerusalem Studies in Arabic and Islam 9: 87-16o.

Brett, Michael. 2005. "Population and conversion to Islam in Egypt in the Medieval period." Pages 1-32 in Egypt and Syria in the Fatimid, Ayyubid and Mamluk Eras. Proceedings of the gth and 1oth International Colloquium organized at the Katholieke Universiteit Leuven in May 2000 and May 2001. Edited by Urban Vermuelen and Jo Van Steenbergen. Leuven: Peeters.

Cohen, Mark R. 1999. "What was the pact of "Umar? A literary-historical study." Jerusalem Studies in Arabic and Islam 23: 100-57. 
David-Weill, Jean. 1951-52. “Un papyrus inédit du Musée du Louvre." Semitica 4: 67-71. Delattre, Alain, Perrine Pilette and Naïm Vantieghem. 2015. "Papyrus coptes de la Pierpont Morgan Library I: Cinq documents du monastère de Baouit." Journal of Coptic Studies 17: 33-53.

Denoix, Sylvie. 1986. "Les ostraca de Isțabl 'Antar." Annales Islamologiques 22: 27-33.

Diem, Werner. 1984. "Einige frühe amtliche Urkunden aus der Sammlung Papyrus Erzherzog Rainer (Wien)." Le Muséon 97: 109-58.

Diem, Werner. 1997. Arabische Briefe des 7. bis 13. Jahrhunderts aus den Staatlichen Museen Berlin. Documenta Arabica Antiqua 4. Wiesbaden: Harrassowitz.

Diem, Werner. 2008. Arabische Steuerquittungen des 8. bis 11. Jahrhunderts aus der Heidelberger Papyrussammlung und anderen Sammlungen. DAA 5. Wiesbaden: Harrossowitz.

Diem, Werner. 2018. Vier Studien zu arabischen Dokumenten des 8.-14. Jahrhunderts. Wiesbaden: Harrossowitz.

Dridi, Audrey. 2015. "Christian and Jewish communities in Fusțāț: Non-Muslim topography and legal controversies in the pre-Fatimid period." Pages 107-32 in The Late Antique World of Early Islam. Muslims among Christians and Jews in the Eastern Mediterranean. Edited by Robert Hoyland. Princeton: Darwin.

Fenton, Paul B. 1995. "Sa‘dyā ben Yōsēf." Volume 8, pages 661-62 in Encyclopaedia of Islam. Edited by Peri J. Bearman, Thierry Bianquis, Clifford E. Bosworth, Emeri J. van Donzel and Wolfhart P. Heinrichs. Leiden: Brill.

Fiey, Jean-Maurice. 1963. “Tagrit: Esquisse d"histoire chrétienne." L'Orient Syrien 8: 289-342.

Gardner, Iain. 1996. Kellis Literary Texts. Vol.1. Oxford: Oxbow, 1996.

Gascou, Jean. 1978. "Ostrakon grec tardif de l'IFAO." Bulletin de l'institut Français d'archéologie orientale 78: 227-30.

Gayraud, Roland-Pierre, Sophia Björnesjö and Sylvie Denoix. 1986. "Isțabl 'Antar (Fostat) 1985. Rapport de fouilles." Annales Islamologiques 22: 1-26.

Grohmann, Adolf. 1938a. Arabic papyri from the Egyptian Library III. Cairo: Egyptian Library Press.

Grohmann, Adolf. 1938b. "Ein arabischer Steuerpapyrus aus der Sammlung der Papyrus Erzherzog Rainer." Zeitschrift für die neutestamentliche Wissenschaft 37: 52-53.

Grohmann, Adolf. 1943. "Arabische Papyri aus der Sammlung Carl Wessely im Orientalischen Institute zu Prag." Archiv Orientální 14: 161-26o.

Grohmann, Adolf. 1952a. From the World of Arabic Papyri. Cairo: al-Maaref Press.

Grohmann, Adolf. 1952b. Arabic Papyri from the Egyptian Library IV. Cairo: Egyptian Library Press.

Hanafi, Alia. 2004. "Two unpublished paper documents and a papyrus." Pages $45^{-62}$ in Papyrology and the History of Early Islamic Egypt. Edited by Petra M. Sijpesteijn and Lennart Sundelin. IHC 35. Leiden: Brill. 
Hinds, Martin and Hamdi Sakkout 1981. "A letter from the governor of Egypt to the king of Nubia and Muqurra concerning Egyptian-Nubian relations in 141/758." Pages 20929 in Studia Arabica et Islamica: Festschrift for Ihsān 'Abbās on His Sixtieth Birthday. Edited by Wadād al-Qāḍi. Beirut: American University of Beirut.

Hoyland, Robert G. 1997. Seeing Islam as Others Saw It: A Survey and Evaluation of Christian, Jewish, and Zoroastrian Writings on Early Islam. SLAEI 13. Princeton, NJ: Darwin.

Hunt, Lucy-Anne. 2003. "Stuccowork at the monastery of the Syrians in the Wadi al-Natrun: Iraqi- Egyptian artistic contact in the 'Abbasid period." Pages 93-127 in Christians in the Heart of Islamic Rule: Church Life and Scholarship in 'Abbasid Iraq. Edited by David R. Thomas. Leiden: Brill.

Ibn 'Abd al-Hakam. 1922. Futūh Miṣr: The History of the Conquests of Egypt, North Africa and Spain, Edited by Charles C. Torrey. New Haven, CT: Yale University Press.

Ibn al-Bițrīq. 1985. Das Annalenwerk des Eutychios von Alexandrien: Ausgewählte Geschichten und Legenden kompiliert von Sà̃d ibn Bațīq um 935 A.D. Translated and edited by Michael Breydy. Leuven: Peeters.

Ibn Duqmāq. 1893. Kitāb al-intiṣār li-wāsițat 'iqd al-amṣār: Description de l'Égypte, Edited by Karl Vollers. Cairo: Impremerie Nationale.

Ilan, Tal. 2016. "The Jewish community in Egypt before and after 117 CE in light of old and new papyri." Pages 203-24 in Jewish and Christian Communal Identities in the Roman World. Edited by Yair Furstenberg. AJEc 94. Leiden: Brill.

Jahn, Karl. 1937. "Vom frühislamischen Briefwesen: Studien zur islamischen Epistolographie der ersten drei Jahrhunderte der Hiğra auf Grund der arabischen Papyri." Archiv Orientální 9: 153-200.

St John the Almsgiver 1980-1981. The Life of Saint John the Almsgiver. 2 vols. Edited by Kenneth Urwin. London: Anglo-Norman Text Society.

John of Nikiou and Hermann Zotenberg. 1916. The Chronicle of John, Bishop of Nikiu: Translated from Zotenberg's Ethiopic Text. Edited and translated by Robert H. Charles. London: Williams \& Norgate.

Kennedy, Hugh. 1998. "Egypt as a province in the Islamic caliphate." Pages 62-85 in The Cambridge History of Egypt, Volume I: Islamic Egypt, 640-1517. Edited by Carl F. Petry. Cambridge: Cambridge University Press.

Khan, Geoffrey. 1992. Arabic Papyri: Selected Material from the Khalili Collection. Oxford: Oxford University Press.

al-Kindī. 1912. Kitāb al-wulāt wa-kitāb al-quḍāt. Edited by Reuven Guest. Leiden: Brill.

Lev, Yaacov. 2012. "Coptic rebellions and the Islamization of Medieval Egypt (8th-10th century): Medieval and modern perceptions." Jerusalem Studies in Arabic and Islam 39: 303-44. 
Levy-Rubin, Milka. 2016. "Umar II's ghiyār edict: Between ideology and practice." Pages $157-72$ in Christians and Others in the Umayyad State. Edited by Antoine Borrut and Fred M. Donner. LAMINE 1. Chicago: The Oriental Institute.

al-Maqrīzī. 2002-2004. Al-Mawā'iz wa-l-i'tibār fì dhikr al-khițaț wa-l-āthār. 5 vols. Edited by Ayman F. Sayyid. London: Al-Furqān Islamic Heritage Foundation.

Mikhail, M. 2014. From Byzantine to Islamic Egypt: Religion, Identity and Politics after the Arab Conquest. London: Al-Furqān Islamic Heritage Foundation.

O'Connell, Elizabeth R. (forthcoming), Egypt, Empire and the Formation of Religious Identity (c. 30BC-AD19oo). British Museum Publications on Egypt and Sudan 11. Leuven: Peeters.

Olszowy-Schlanger, Judith. 2006. "Les plus anciens documents datés de la Guenizah du Caire: Lectures et relectures." Livret-Annuaire de l'EPHE 20: 47-5०.

Papaconstantinou, Arietta. 2007. "They shall speak the Arabic language and take pride in it": Reconsidering the fate of Coptic after the Arab conquest." Le Muséon 120 : 273-99.

Papaconstantinou, Arietta. 2008. "Dioscore et la question du bilinguisme dans l'Égypte du vie siècle" pages 77-88 in Jean-Luc Fournet (ed.), Les archives de Dioscore d'Aphrodité cent ans après leur découverte. Paris: De Boccard.

Papaconstantinou, Arietta. 2009. "What remains behind: Hellenism and romanitas in Christian Egypt after the Arab conquest." Pages 447-66 in From Hellenism to Islam: Cultural and Linguistic Change in the Roman Near East. Edited by Hannah M. Cotton, Robert Hoyland, Jonathan Price and David Wasserstein. Cambridge: Cambridge University Press.

Rāgib, Yūsuf. 1981. "Lettres nouvelles de Qurra b. Šarīk." Journal of Near Eastern Studies 40: $173-87$.

Van Rompay, Lucas. 2008. "Syriac and related scripts in Egypt." Pages 150-63 in Journey of Writing in Egypt. Edited by Khālid Azab and Ahmed M. Mansour. Alexandria: Bibliotheca Alexandria.

Rustow, Marina. 2008. Heresy and the Politics of Community: The Jews of the Fatimid Caliphate. Ithaca, NY: Cornell University Press.

Shaked, Shaul. 2010. "Persian-Arabic bilingualism in the Cairo Genizah documents." Pages 319-30 in 'From a Sacred Source': Genizah studies in honour of Stefan C. Reif. Edited by Ben Outhwaite and Siam Bhayro. Leiden: Brill.

Sijpesteijn, Petra M. 20o6. "The archival mind in early Islamic Egypt: Two Arabic papyri." Pages 163-86 in From al-Andalus to Khurasan: Documents from the Medieval Muslim World. Edited by Petra M. Sijpesteijn et al. IHC 66. Leiden: Brill.

Sijpesteijn, Petra M. 2011. "Building an Egyptian identity." Pages 85-106 in The Islamic Scholarly Tradition: Studies in history, law and thought in honor of professor Michael Allan Cook. Edited by Asad Q. Ahmed, Michael Bonner and Behnam Sadeghi. IH C 83. Leiden: Brill. 
Sijpesteijn, Petra M. 2013. Shaping a Muslim State: The World of a Mid-Eighth-Century Egyptian Official. Oxford Studies in Byzantium. Oxford: Oxford University Press.

Sijpesteijn, Petra M. 2017. "Delegation of judicial power in Abbasid Egypt." Pages 61-84 in Legal Documents as Sources for the History of Muslim Societies: Studies in honour of Rudolph Peters. Edited by Maaike van Berkel, Léon Buskens and Petra M. Sijpesteijn. SILS 42. Leiden: Brill.

Sijpesteijn, Petra M. 2020. "Establishing local elite authority in Egypt through arbitration and mediation." Pages 387-406 in Transregional and Regional Elites Connecting the Early Islamic Empire. Edited by Hannah-Lena Hagemann and Stefan Heidemann. Berlin: De Gruyter.

Sirat, Colette. 1985. Les papyrus en caractères hébraïques trouvés en Égypte. Paris: ECNRS. Smelik, Willem F. 2012. "Justinian's Novella 146 and contemporary Judaism." Pages 14163 in Greek Scripture and the Rabbis. Edited by Timothy M. Law and Alison Salvesen. Leuven: Peeters.

Starr, Joshua. 1935. "Byzantine Jewry on the eve of the Arab conquest (565-638)." Journal of the Palestine Oriental Society 15: 280-93.

Stiefel, Barry L. 2014. Jews and the Renaissance of Synagogue Architecture, 1450-1730. London: Pickering \& Chatto.

Stillman, Norman A. 1997. "The non-Muslim communities: The Jewish community." Pages 198-210 in Cambridge History of Egypt I. Edited by Carl F. Petry. Cambridge: Cambridge University Press.

Stroumsa, Guy G. 2012. "Jewish survival in Late Antique Alexandria." Pages $257-70$ in Jews in Byzantium: Dialectics of Minority and Majority Cultures. Edited by Robert Bonfil, Oded Irshai, Guy G. Stroumsa and Rina Talgam. Jerusalem Studies in Religion and Culture 14. Leiden : Brill.

Tannous, Jack. 2018. The Making of the Medieval Middle East. Religion, Society, and Simple Believers. Princeton \& Oxford: Princeton University Press.

Vantieghem, Naïm. 2014. "Contrats de location arabes II." Chronique d'Égypte 89: 210-15. Yarbrough, Luke. 2016. "Did 'Umar b. 'Abd al-'Azīz issue an edict concerning nonMuslim officials?" Pages 173-206 in Christians and Others in the Umayyad state. Edited by Antoine Borrut and Fred M. Donner. LAm InE 1. Chicago, IL: The Oriental Institute. 